\title{
Pengembangan Literasi dan Implementasi Kebijakan Publik dan Dampaknya Terhadap Peningkatan Pengetahuan Masyarakat Bersama Lembaga Mandiri Nafis Fondation Dalam Perspektif Hukum Bisnis
}

\author{
Hapipi Jayadi ${ }^{1}$, Reni Anggriani ${ }^{2}$, Yulia Candri Rahayu ${ }^{3}$, Mufidah 4, \\ Nasuhi 5 , Didin Hadi Saputra ${ }^{6 *}$, Masdani 7 \\ 1, 2, 3, 4, 5, 6 Administrasi Publik/Universitas Nahdlatul Wathan Mataram \\ 7 Pendidikan Agama Islam/Universitas Nahdlatul Wathan Mataram \\ ${ }^{1}$ hapipijayadi@gmail.com, ${ }^{2}$ renianggriani@gmail.com, ${ }^{3}$ candri@gmail.com, ${ }^{4}$ muff5910@gmail.com, \\ ${ }^{5}$ nasuhi@gmail.com, ${ }^{6 *}$ didinhs@unwmataram.ac.id, ${ }^{7}$ danivazaki@gmail.com
}

\begin{abstract}
Abstrak
Makna dari sebuah kegiatan pengabdian kepada masyarakat yakni salah satu pendekatan baik secara filosofis maupun secara akademik kepada kelompok tertentu dalam rangka memberikan pencerahan ataupun literasi kepada mereka/masarakat, agar mereka mampu memahami akan fungsi dan tugas sebuh institusi perguruan tinggi. Metode dalam pelaksanaan program pengabdian masyarakat dalam memberikan literasi tentang kebijakan pemerintah dalam perspektif hukum bisnis bersama lembaga Nafis Fondation di Desa Lekor Kecamatan Janapria Kabupaten Lombok Tengah dilakukan dengan beberapa tahapan pelaksanaan program. Manfaat serta dampak dan kelebihan dari pelaksanaan dari pengabdian ini, yakni masyarakat lebih mengetahui serta lebih faham tentang pungutan dari PNBP, bukan hanya sekedar bernama "pungutan liar" saja seperti yang didengungkan selama ini, namun PNBP merupakan salah satu pungutan langsung berdasarkan Undang - Undang tentang Ketentuan dan Tata Cara Perpajakan (KUP). Kesimpulan dari pengabdian ini adalah tingginya minat masyarakat dalam mengetahui masalah literasi PNBP, dan terdapat perubahan pola perilaku masyarakat desa yang mulai memahami dan membiasakan diri untuk memilah informasi yang benar tentang PNBP atau Penerimaan Negara Bukan Pajak.
\end{abstract}

Kata Kunci: Kebijakan Publik, Nafis Fondation, PNBP, Desa Lekor

\section{Pendahuluan}

Dalam menjalankan kegiatan Tri Dharma Perguruan Tinggi, salah satu yang menjadi tujuan pokok seorang akademisi yakni menjalankan pengabdian kepada masyarakat. Makna dari sebuah kegiatan pengabdian kepada masyarakat yakni salah satu pendekatan baik secara filosofis maupun secara akademik kepada kelompok tertentu dalam rangka memberikan pencerahan ataupun literasi kepada mereka/masarakat, agar mereka mampu memahami akan fungsi dan tugas sebuh institusi perguruan tinggi. 
Kegiatan pemberdayaan atau pengabdian kepada masyarakat merupakan suatu pendekatan atau suatu kegiatan yang memperhatikan seluruh aspek potensi dalam kehidupan masyarakat di lokasi pengabdian tersebut. Sasaran dari kegiatan pengabdian kali ini adalah seluruh lapisan masyarakat yang ada dalam wilayah misalnya dalam suatu desa. Sedangkan motif dari kegiatan ini adalah membantu masyarakat agar mampu berdikari, serta dapat membangkitkan kemampuan self-help untuk meningkatkan kualitas hidup masyarakat (modernisasi) itu sendiri yang mengacu pada cara berpikir, bagaimana bersikap terhadap perubahan, berperilaku untuk maju. Maka bidang pemberdayaan merupakan titik strategis yang harus diperbarui dan diperluas. Dengan demikian esensi dari pemberdayaan masyarakat di pedesaan adalah pemberdayaan sumber daya (potensi) lokal yang dapat meningkatkan partisipasi dan memupuk kepedulian semua pihak untuk kemandirian (berdikari) masyarakat.

Pengabdian ini mengambil tema besar tentang "Membangun Literasi Masyarakat Terhadap Kebijakan Pemerintah Dalam Perspektif Hukum Bisnis". Permasalahan yang sering terjadi dan sesekali di beberapa tempat terkadang masih menjadi perdebatan serta menarik untuk tim pengabdi bahas melalui literasi dalam pengabdian kali ini adalah masih kurangnya pemahaman masyarakat terhadap berbagai jenis kebijakan publik yang ada di masyarakat, terutama yang berkaitan dengan hukum bisnis yakni PNBP atau Penerimaan Negara Bukan Pajak. Selama ini, pengetahuan masyarakat tentang PNBP atau Penerimaan Negara Bukan Pajak selalu identik dengan pungli atau pungutan liar, namun bila ditinjau lebih jauh, literasi dalam pengabdian ini adalah yang ingin diberikan pemahaman oleh tim pengabdi kepada masyarakat pengabdian.

Sedangkan tujuan dari kegiatan pengabdian berbentuk literasi "sharing knowledge" ini adalah untuk memberikan pemahaman, edukasi, serta memberikan pengetahuan dasar kepada masyarakat tentang apa itu PNBP, fungsi PNBP, kapan PNBP bisa di pungut kepada masyarakat?, apa regulasi dan peraturan Undang Undang yang melindungi kegiatan pungutan PNBP?, serta apa manfaat yang dirasakan baik secara langsung ataupun tidak langsung oleh masyarakt terhadap PNPB itu sendiri. Begitu pula dengan bagaimana mendakwahkan atau mensosialisasikan penerapan regulasi dalam perspektif ajarn Islamm agar mearih masyarakat yang mandiri serta moderat.

Ruang lingkup dari pengabdian ini adalah tentang bagian dari kebijakan publik yakni penetapan PNBP. Selain itu, pengabdian ini juga banyak mengupas atau memberikan pemahaman tentang bagaimana fungsi dan manfaat PNBP terhadap peningkatan kesejahteraan masyarakat secara tidak langsung di lokasi tim pengabdi. Selain itu, kondisi masyarakat lokasi pengabdian juga sangat antusias dengan kegiatan pengabdian ini. Mereka menganggap pengabdian selama hanya sebatas kunjungan seremonial semata, dan tidak pernah datang lagi untuk memberikan literasi lanjutan tentang apa dan bagaiman pendampingan berkelanjutan terhadap masyarakat yang kami kunjungi. Tujuan yang diharapkan dari kegiatan pengabdian ini yakni agar masyarakat lokasi tim pengabdi merasakan manfaat secara tidak langsung pungutan PNBP yang disertai dengan Undang Undang tentang Ketentuan Umum dan Tata Cara Perpajakan (KUP).

\section{Metode Pelaksanaan}

Metode dalam pelaksanaan program pengabdian masyarakat dalam memberikan literasi tentang kebijakan pemerintah dalam perspektif hukum bisnis di Desa Lekor 
Kecamatan Janapria Kabupaten Lombok Tengah dilakukan dengan beberapa tahapan pelaksanaan program, yaitu sebagai berikut:

\section{Tahapan awal}

a. Tahapan ini dilakukan oleh para dosen yang melakukan pengabdian dengan menyiapkan data-data yang dibutuhkan terkait masyarakat Desa Lekor Kecamatan Janapria Kabupaten Lombok Tengah. Hal ini dibutuhkan untuk memastikan pendampingan seperti apa yang tepat dengan juga melihat kultur di Desa yang bersangkutan sebagai pertimbangan.

b. Menyiapkan program-program pengabdian masyarakat untuk di sosialisasikan kepada masyarakat Desa Lekor Kecamatan Janapria Kabupaten Lombok Tengah dengan target utama membuat masyarakat memahami apa itu PNBP secara utuh dan menyeluruh.

c. Menyiapkan peralatan, sarana-prasarana pendukung untuk pelaksanaan program dan formula strategi pelaksanaan program secara tahap demi tahap berdasarkan prioritas program pendampingan Desa Lekor Kecamatan Janapria Kabupaten Lombok Tengah.

\section{Tahapan pelaksanaan}

a. Mengemukakan strategi proses pelaksanaan program literasi masyarakat Desa Lekor untuk menerapkan pola manajemen terhadap mitra sehingga diharapkan memberikan dampak dan perubahan terhadap mitra sasaran program sesuai dengan tujuan pengabdian masyarakat.

b. Tahapan pelaksanaan ini merupakan adanya komunikasi sinergi dengan mitra terkait keaktifan, peran dan kontribusi mitra sasaran pelaksanaan program pengabdian masyarakat.

c. Dalm proses pengabdian masyarakat akan dilakukan terus koordinasi terkait progress dari pengabdian masyarakat ini.

\section{Tahapan monitoring dan evaluasi}

a. Proses monitoring dan evaluasi terhadap pelaksanaan program dilakukan setiap minggu dalam 3 (tiga) bulan masa pengabdian masyarakat Desa Lekor Kecamatan Janapria Kabupaten Lombok Tengah.

b. Metode evaluasinya yang digunakan menggunakan metode deskriptif yaitu penelitian lapangan (Field Research) dengan penyelidikan mendalam yang dilakukan dengan suatu prosedur penelitian lapangan. Penelitian ini juga menggunakan data deskriptif kualitatif, yaitu penelitian yang ditujukan untuk mendiskripsikan atau menggambarkan fenomenafenomena yang ada, baik fenomena yang bersifat alamiah ataupun rekayasa manusia

\section{Tahap pelaporan}

Pada tahapan ini, dilaporkan semua proses rangkaian kegiatan pengabdian dan output dari kegiatan ini. 


\section{Hasil dan Pembahasan}

Berdasarkan hasil dari pengabdian masyarakat dengan program literasi tentang kebijakan pemerintah dalam perspektif hukum bisnis di Desa Lekor Kecamatan Janapria Kabupaten Lombok Tengah dapat dijelaskan hasil dan luaran program serta dampaknya terhadap perubahan mitra selama proses pendampingan menghasilkan pemahaman sederhana tentang PNBP dan mengalami peningkatan secara signifikan semangat dan lebih ingin tahu banyak tentang cara penerapan, manfaat serta hasil PNBP di masyarakat secara umum.

Dampak dari program pengabdian masyarakat ini yang dikolaborasikan dengan program pendampingan serta literasi masyarakat terhadap mitra pengabdian, mereka sangat antusias sekali, dan sangan besar keinginan mereka untuk dikunjungi lagi dimasa yang akan datang. Terkait dengan tingkat pengetahuan masyarakat di Desa Lekor atau di lokasi pengabdian, selama ini umumnya masyarakat kerap bertanya, untuk apa PNBP atau Penerimaan Bukan Pajak tersebut dipungut oleh pemerintah daerah. Ketidak tahuan masyarakat inilah yang menjadi menjadi fokus pengabdian kami di Mufis Fondation data setiap bulan dengan rentang waktu pendampingan selama 3 (tiga) bulan dari bulan agustus, September dan Oktober tahun 2020. Perlu diketahui bahwa dalam penyelenggaraan pengabdian ini melibatkan 7 (tujuh) orang dosen, yakni masing masing 6 dari Fakultas Ilmu Administrasi dan 1 dari Fakultas Agama Islam. Pendekatan yang dilakukan adalah pendekatan manajemen kemasyarakatan berbasis literasi.

Untuk dapat memenuhi kebutuhan pemetaan kualitas berdasarkan pencapaian sasaran mutu, maka tim Abdimas UNW Mataram akan terus secara sustainable atau berkelanjutan untuk membantu serta memberi pendampingan kepada masyarakat Desa Lekor agar lebih memahami serta mengerti arti dan makna filosofis dari pemungutan PNBP (Penerimaan Negara Bukan Pajak) kepada masyarakat (Pramuniati et al., 2020)

Kegiatan monitoring dan evaluasi merupakan kegiatan pengendalian internal agar pelaksanaan kegiatan pengabdian berjalan dengan lancar. Kegiatan pengabdian ini dilakukan oleh tim pelaksana baik secara langsung maupun tidak langsung. Setiap kali dilakukan monitoring, selanjutnya dilakukan analisis evaluasi berdasarkan hasil monitoring. Evaluasi secara keseluruhan dilakukan melalui diskusi hasil monitoring dan evaluasi anggota tim. Hasil kegiatan monitoring dan evaluasi ini berupa saran/masukan kepada peserta maupun pembimbing dalam melaksanakan kegiatannya agar pencapaiannya sesuai yang direncanakan atau bahkan lebih baik lagi (Nasution et al., 2020).

Pentingnya kegiatan pengabdian kali ini, merupakan hasil dari survey awal atau hasil pemetaan masalah serta analisis perdana tim pengabdi Universitas Nahdlatul Mataram. Tim kecil yang terdiri dari 3 orang melakuan tinjauan awal menuju subyek pengabdian, hasil survey tersebut menjad dasar utama dalam melakuan pemetaan, pengorganisasian, serta merencanakan turun lapangan bersama tim lengkap pengabdian dari beberapa fakultas di Universitas Nahdlatul Wathan Mataram. 


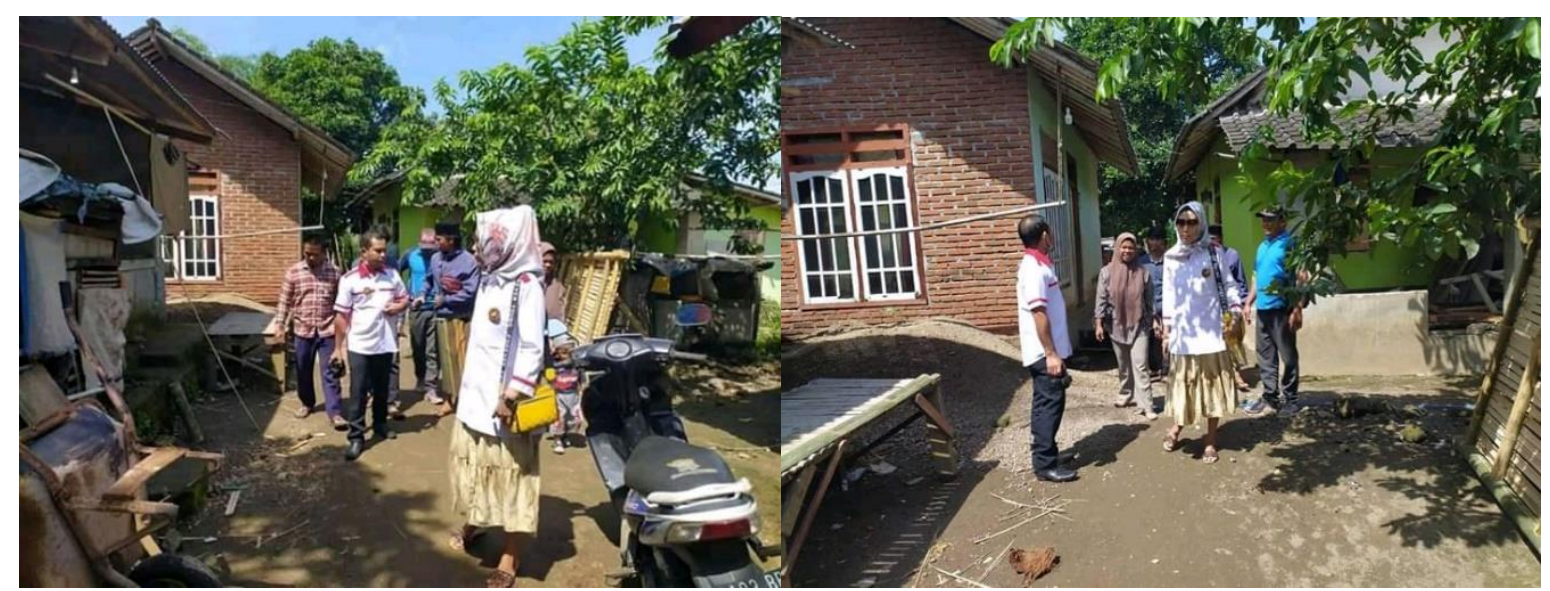

Gambar 1. Tim Abdimas melakukan survey awal di Desa Lekor

Survey awal pemetaan masalah diatas merupakan dasar dari kegiatan pengabdian masyarakat ini terlaksana. Berbagai bentuk kegiatan pengabdian yang dilaksanakan oleh Universitas Nahdlatul Wathan (yang dalam hal ini melibatkan Mufis Fondation), merupakan salah satu bentuk pengabdian yang berjejaring dan berprinsip "link and match" serta tersistem dan terintegrasi dengan berbagai dharma perguruan tinggi lainnya, yakni Dharma Pengajaran dan Dharma Penelitian.

Banyak manfaat serta dampak dan kelebihan dari pelaksanaan dari pengabdian ini, yakni masyarakat lebih mengetahui serta lebih faham tentang pungutan dari PNBP, bukan hanya sekedar bernama "pungutan liar" saja sepetti yang didengungkan selama ini, namun PNBP merupakan salah satu pungutan langsung berdasarkan Undang Undang tentang Ketentuan dan Tata Cara Perpajakan (KUP). Selanjutnya untuk lebih menguatkan serta mengembangkan kapasitas serta penguatan kualitas dari pengabdian ini, akan ada tindak lanjut dari pengabdian ini. Pengabdian ini meliputi segala aspek penting dalam manajemen kebijakan public serta perluasan literasi menuju wilayah sekitar desa sekitar (Munawarah et al., 2020).

Meski peserta pengabdian masih dibayangi suasana Pandemi Covid-19, namun antusisasme masyarakat sangat tinggi dalam pengabdian ini. Pengabdian masyarakat ini diberikan dalam tiga kegiatan inti, yaitu edukasi, keterampilan, dan pendampingan. Kegiatan edukasi merupakan aktivitas pengabdian yang diberikan secara rutin oleh akademisi guna memenuhi Tri Dharma Pendidikan Tinggi, yaitu memberikan pemahaman atas konsep PNBP dalam pandangan kebijakan publi serta dalam pandangan hukum bisnis. Edukasi diberikan untuk memberikan pengetahuan teoritis kepada peserta mengenai peran dari masing - masing bidang ilmu, yaitu bisnis, hukum dan kebijakan.

Edukasi tidak semata mata sosialisasi satu arah dari pihak akademisi, melainkan media bertukar informasi dan membuka diskusi dengan peserta pengabdian. Pengetahuan tentang PNBP serta dampaknya secara tidak langsung pada masyarakat (Aulia Rahmi et al., 2020). 


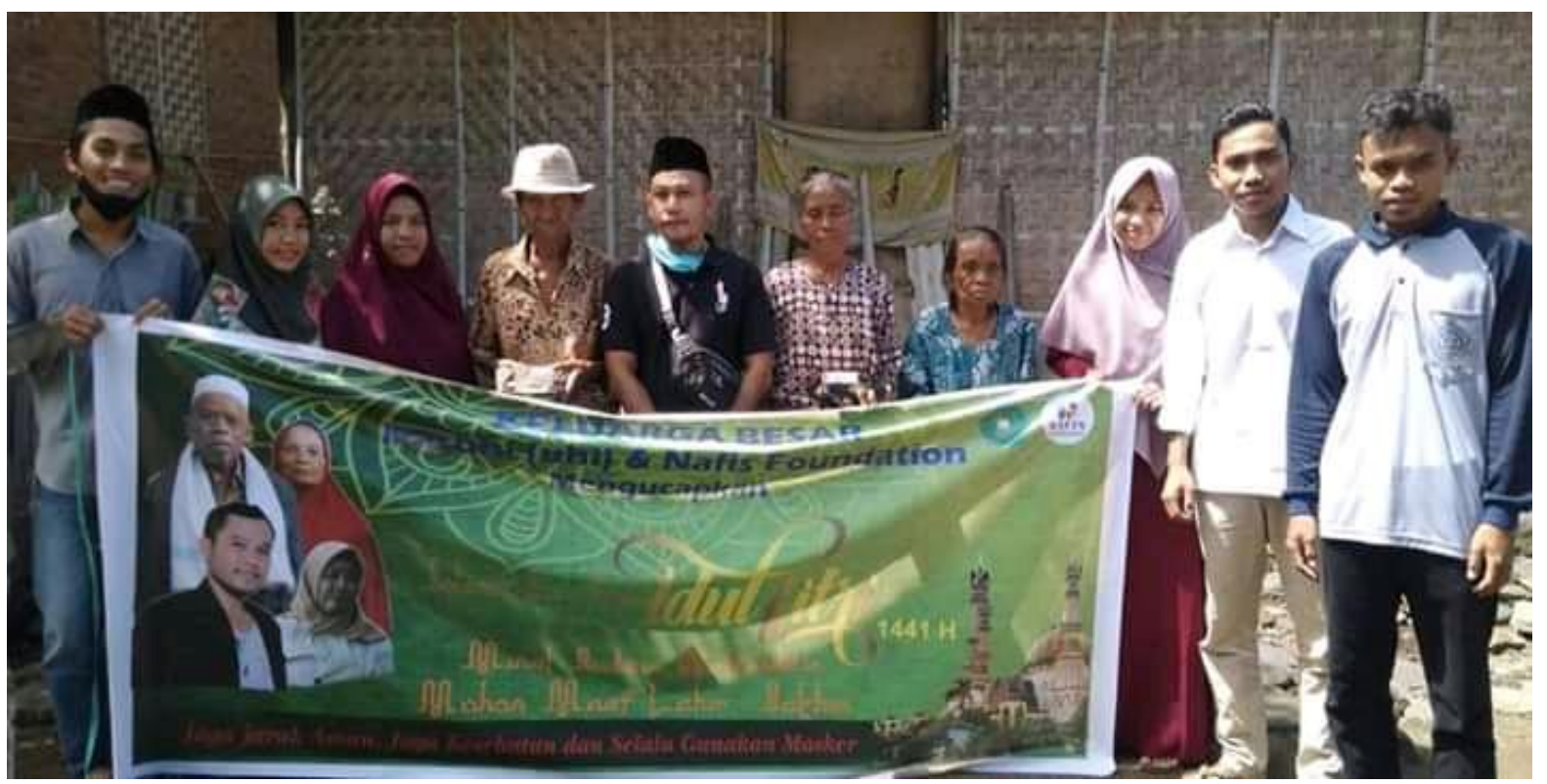

Gambar 2. Tim Abdimas melakukan survey awal di Desa Lekor

\section{Kesimpulan}

Secara keseluruhan kegiatan pengabdian ini berjalan lancar dan di ikuti secara penuh antusiasme oleh masyarakat Desa Lekor. Beberapa hal yang dapat disimpulkan mengenai hasil pengabdian masyarakat, antara lain tingginya minat masyarakat dalam mengetahui masalah literasi; terdapat perubahan pola perilaku masyarakat desa yang mulai memahami dan membiasakan diri untuk memilah informasi yang benar tentang PNBP atau Penrimaan Negara Bukan Pajak; serta antusiasme masyarakat terhadap sosialisasi ini sangat tinggi, karena menghasilkan pengetahuan baru buat mereka mengenai PNBP

\section{Ucapan Terimakasih}

Tim pengabdian dari beberapa fakultas di Universitas Nahdlatul Wathan Mataram menyampaikan apresisasi dan penghargaan yang setinggi - tingginya kepada para tim pengabdi, serta lembaga Mufis Foundation yang telah menjadi mitra pengabdian kali ini. Tim pengabdi juga menyampaikan terima kasih yang tiada terhingga kepada masyarakat Desa Lekor atas segala dukungan survey lokasi pengabdian, serta dukungan terjadap terselenggaranya acar pengabdian ini. Tak lupa lupa tim menyampaikan penghargaan yang tiada terhingga pada mahasiswa yang telah mendukung sejak perencanaan hingga rapat rutin serta pada tahap pengevaluasian pengabdian ini. Tim pengabdian juga memberikan apresiasi kepada Universitas Nahdlatul Wathan Mataram, terutama Fakultas Ilmu Administrasi serta Fakultas Agama Islam yang telah bergabung dalam salah satu dharma, yaitu dharma pengabdian, serta Kepala Desa Lekor, Lombok Tengah atas dukungan baik perijinan, fasilitas maupun koordinasi, sehingga seluruh rangkaian kegiatan pengabdian masyarakat di tengah pandemi wabah "Covid 19" dapat terlaksana dengan lancar. 
Vol. 2, No. 1, Februari 2021

ISSN 2721-4834

\section{Referensi}

Munawarah, M., Hayati, K., Purba, M. I., \& Ginting, W. A. (2020). Pemberdayaan Masyarakat Kelurahan Suka Maju Melalui Pelatihan Pembuatan Sabun Kebutuhan Rumah Tangga. Dinamisia : Jurnal Pengabdian Kepada Masyarakat, 4(3), 434-439. https://doi.org/10.31849/dinamisia.v4i3.3910

Nasution, R. D., Saragih, F. H., \& Sembiring, P. S. M. A. (2020). Pendampingan Sistem Pembelajaran Online Berbasis Aplikasi Google Meet Bagi Guru-Guru Smp It Daarul Istiqlal Dan Smp It Rahmat Marindal I, Kecamatan Patumbak, Kabupaten Deli Serdang. Jurnal Pengabdian Kepada Masyarakat, 26(4), 188. https://doi.org/10.24114/jpkm.v26i4.20365

Pramuniati, I., Arnita, A., \& Taufik, I. (2020). Pengembangan Sistem Penjaminan Mutu Sekolah Berbasis Digital Di Sma Negeri 2 Tebing Tinggi. Jurnal Pengabdian Kepada Masyarakat, 26(4), 200. https://doi.org/10.24114/jpkm.v26i4.20579

Rahmi, V. A., Ismanto, H., \& Fathoni, M. Z. (2020). Inovatif Saat Pandemi Covid Melalui Pelatihan Kewirausahaan Khas Perempuan Berbahan Sampah "Kolaborasi BUMDes dan Warga." Dinamisia : Jurnal Pengabdian Kepada Masyarakat, 4(3), 418-425. https://doi.org/10.31849/dinamisia.v4i3.4632 